Reprod. Nutr. Dévelop., 1980, 20 (3 A), 699-708.

\title{
Growth of anuran oocytes in serum-supplemented medium
}

\author{
par R. A. WALLACE, Ziva MISULOVIN, H. S. WILEY* \\ Biology Division, Oak Ridge National Laboratory, P. O. B. Y, Oak Ridge, TN 37830 (U. S. A.). \\ * University of Tennessee. Oak Ridge Graduate School of Biomedical Sciences, \\ Oak Ridge, TN 37830 (U. S. A.).
}

\begin{abstract}
Summary. Appropriately-sized oocytes from Xenopus laevis can be grown in vitro in vitellogenin-containing serum for up to 2 weeks. The source of serum appears to be unimportant. Rates of oocyte growth are somewhat better than those achieved in the presence of vitellogenin alone. Rana pipiens oocytes grow about twice as fast as $X$. laevis oocytes under identical conditions. The oocyte culture conditions described appear to be applicable to amphibian oocytes in general.
\end{abstract}

\section{Introduction.}

We have recently described the growth and differentiation of Xenopus laevis oocytes in a defined medium (Wallace ef al., 1978 ; Wallace and Misulovin, 1978). The essential features of our procedure included (1) manual dissection of oocytes from their outer follicular layers, and (2) incubation of the isolated oocytes in an appropriate nutrient medium containing vitellogenin, the macromolecular precursor to yolk proteins. No serum supplement was used, since we found in our initial explorations that it did not seem to be particularly beneficial (Wallace ef al., 1978). One of the prerequisites for oocyte culture, therefore, was the isolation of vitellogenin from the blood of $X$. laevis.

Large-scale isolation and purification of vitellogenin may prove difficult or inconvenient for some who lack the appropriate facilities. Furthermore, most workers will probably not require a defined medium for the purpose of their research. We have, therefore, re-explored the use of vitellogenin-containing serum as a simplified procedure for culturing the oocytes of $X$. laevis and those of a distantly related anuran, Rana pipiens. We document here some of our findings, including the optimum conditions for oocyte growth.

\section{Materials and methods.}

Animals and chemicals. $-X$. laevis males and females were obtained from South Africa (South African Snake Farm, Fish Hok, Cape Province), and R. pipiens females were purchased from the Amphibian Facility (University of Michigan, Ann Arbor, Mi). 
When obtained, females from both species had asynchronous ovaries, i. e., oocytes could be found in all stages of development. $X$. laevis were kept at $20^{\circ} \mathrm{C}$ in running, dechlorinated water and fed a diet of chopped beef heart and liver supplemented with 2 p. 100 Clovite (Fort Dodge Laboratories, Fort Dodge, IA) ; R. pipiens were kept in damp terrania at room temperature $\left(20-22^{\circ} \mathrm{C}\right)$ and fed a diet of live crickets and earthworms. In general, $X$. laevis females were injected with a single dose (1 000 units) of human chorionic gonadotropin (hCG) 2-3 days prior to laparotomy ; however, this hormone treatment did not appear to consistently affect growth rates of oocytes subsequently culfured for a week or more. $R$. pipiens females were each injected with 3 female $R$. pipiens pituitaries 5-6 days prior to laparotomy.

Liebovitz L-15 medium, L-glutamine solutions, and fetal calf serum were purchased from Grand Island Biologicals (Grand Island, NY). Estradiol-17 $\beta$, tricaine methanesulfonate, Hepes, gentamycin sulfate, and nystatin were obtained from Sigma Chemical Company (Si-Louis, Missouri). Crude hCG was supplied by Organon Inc. (Orange, New Jersey). Crystalline porcine insulin (Lot 615-D63-10) was a generous gift of Dr. Ronald Chance, Lilly Research Laboratories (Indianapolis, Indiana). Vitellogenin was prepared from the serum of estrogen-treated $X$. laevis females by chromatography on TEAE-cellulose as described previously (Wallace et al., 1978).

Preparation of vitellogenin-containing serum. - We initiated vitellogenin accumulation in the blood by injecting $X$. laevis females with a massive dose of estrogen ( $4 \mathrm{mg}$ estradiol-17 $\beta$ dissolved in $0.4 \mathrm{ml}$ propylene glycol per $100 \mathrm{~g}$ body weight). Females rather than males were used, since we have found that they give a more rapid and consistent response. After 2-3 weeks, estrogen-treated animals were anesthetized by immersion for $30 \mathrm{~min}$ in 0.1 p. 100 tricaine methanesulfonate (made up in tap water) and exhaustively bled into centrifuge tubes by the procedure of Anstall and Huntsman (1960). The blood was allowed to stand for several hours at room femperature before the clot was centrifuged. With care, we could obtain $8-10 \mathrm{ml}$ blood (somewhat more than half of that as serum) from each $100 \mathrm{~g}$ female. The serum was generally dark green and contained $100-150 \mathrm{mg}$ vitellogenin $/ \mathrm{ml}$; it was sterile-filtered through a Cox M-780 type AA 45 filter (Cox Instrument, Detroit, Michigan), divided into small aliquots, and frozen at -20 o $\mathrm{C}$ for up to 3 months for later use. The vitellogenin-containing serum was frozen and thawed only once, and if the serum turned cloudy (lipaemic) upon thawing, it was discarded (ca. 1 out of 20 batches).

Assay for serum vitellogenin titer. - A $100 \mu \mathrm{l}$ aliquot of vitellogenin-containing serum was mixed with $400 \mu \mathrm{l}$ of $20 \mathrm{mM}$ EDTA, $40 \mathrm{mM} \mathrm{MgCl}_{2}(\mathrm{pH}=7.7)$ and then mixed briefly. After the tubes stood for $10 \mathrm{~min}$ at $0^{\circ} \mathrm{C}$, the vitellogenin precipitate was pelleted in a centrifuge at $5000 \mathrm{~g}$ for $10 \mathrm{~min}$; the supernatant was discarded. The pellet was dissolved in $1 \mathrm{M} \mathrm{NaCl}, 50 \mathrm{mM}$ Tris- $\mathrm{Cl}(\mathrm{pH}=7.5)$ to a volume of $5 \mathrm{ml}$. The absorbance of the liquid was measured at $280 \mathrm{~nm}$, and the vitellogenin concentration was estimated by use of an absorptivity value of $0.75 \mathrm{l} / \mathrm{g} . \mathrm{cm}$ (Wallace, 1970). The vitellogenin concentration in the original serum sample was calculated by correcting for the dilution $(50 \mathrm{X}$ ) and adding $2.6 \mathrm{mg} / \mathrm{ml}$ to the determined value (see fig. 1). This 
assay is based on the vitellogenin isolation procedure of Wiley et al. (1979) and a standard curve for the assay is provided in figure 1.

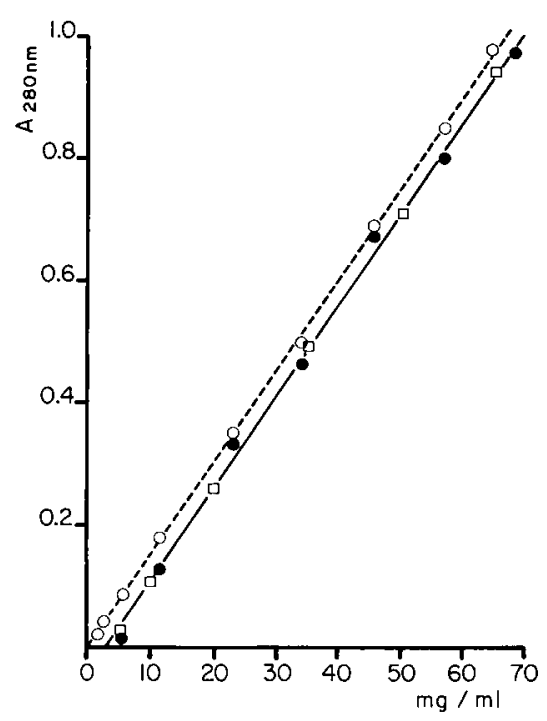

FIG. 1. - Standard curves for $\left[{ }^{32} \mathrm{P}\right]$ vifellogenin assay. A $150-\mathrm{g}$ female was injected with $3 \mathrm{mg} 17 \beta$-estradiol and 10 days later with $2 \mathrm{mCi}$ of [ $\left.{ }^{32} \mathrm{P}\right]$ orthophosphate. The serum was collected $24 \mathrm{~h}$ later. [ $\left.{ }^{32} \mathrm{P}\right]$ Vitellogenin was isolated from a small sample of the serum (Wiley ef al., 1979) and its specific activity determined. Since vitellogenin is the only phosphoprotein present in $X$. laevis serum (Wallace, 1970), the determination of the acid-insoluble ${ }^{32} \mathrm{P}$ counts in delipidated samples allowed us to calculate the absolute amount of [ $\left.{ }^{32} \mathrm{P}\right]$ vitellogenin present in the serum sample. The $\left[{ }^{32 P}\right]$ vitellogenin-containing serum was then diluted with appropriate amounts of normal male serum in order to produce a range of vitellogenin concentrations from 5 to $70 \mathrm{mg} / \mathrm{ml}$. Aliquots $(100 \mu \mathrm{l})$ of the mixtures were then assayed according to the method described in the text. The absorbance at $280 \mathrm{~nm}$ of the final sample dilution is plotted against the known concentration of [ $\left.{ }^{32} \mathrm{P}\right]$ vitellogenin in the original samples. The least squares analysis of the data from two separate experiments $(\square, \bullet)$ is indicated by the solid line. Also included is an example in which samples containing purified $\left[{ }^{32} \mathrm{P}\right]$ vitellogenin in normal saline were assayed $(0)$; the line that should be theoretically obtained is indicated by a dashed line. While the least-squares analysis of the serum data gives a line with a slope $\left(0.015 \mathrm{~A}_{280} . \mathrm{ml} / \mathrm{mg}\right)$ identical to that for serum-free [ ${ }^{32} \mathrm{P}$ ] vitellogenin, the line intercepts the $X$ axis at $2.6 \mathrm{mg} / \mathrm{ml}$ instead of at the origin. In separate experiments we have verified that the assay remains linear up to a vitellogenin concentration of $150 \mathrm{mg} / \mathrm{ml}$ and that serum contains a protein(s) which renders $2.6 \mathrm{mg} / \mathrm{ml}$ vitellogenin resistant to precipitation by $\mathrm{Mg}^{2+}$ and EDTA (results not shown).

Oocyte culture. - Animals were anesthetized by covering with crushed ice for $30 \mathrm{~min}$ (X. laevis) or $60 \mathrm{~min}$ (R. pipiens). A portion of the ovary was excised and placed in sterile O-R2 (Wallace ef al., 1973). Oocytes $(0.80 \pm 0.05 \mathrm{~mm}$ diameter unless specified otherwise) were dissected manually from their follicles with a pair of watchmaker's forceps and placed in a culture medium consisting of 50 p. 100 Liebovitz L-15 medium, $1 \mathrm{mM}$ L-glutamine, $1 \mu \mathrm{g}$ insulin/ml, $15 \mathrm{mM}$ Hepes buffer (final $\mathrm{pH}=7.8$ ), the antibiotics gentamycin $(100 \mu \mathrm{g} / \mathrm{ml})$ and nystatin $(50 \mathrm{units} / \mathrm{ml})$, and the serum supplement. The final recommended supplement consists of that amount of $X$. laevis serum which provides a final vitellogenin concentration in the medium of $2.5 \mathrm{mg} / \mathrm{ml}$; the 
$X$. laevis serum is supplemented with fetal calf serum to yield a combined serum concentration of 10 p. 100 . All operations were performed aseptically in a laminar flow hood. Oocytes were cultured individually in wells containing $100 \mu l$ medium (Micro Test II tissue culture plate No. 3040 with No. 3041 lid ; Falcon Plastics, Oxnard, California). Oocytes in culture were then maintained on a stationary platform at $20^{\circ} \mathrm{C}$ in a dark chamber into which $\mathrm{H}_{2} \mathrm{O}$-saturated air was passed. Medium was changed every 3-4 days by transferring medium rather than oocytes. Oocyte volume was obtained by measuring the diameter with an ocular micrometer; oocyte volume has been found to be directly proportional to protein content (Wallace and Misulovin, 1978).

\section{Results.}

Approximately 25 p. 100 of our attempts at oocyte culture using media supplemented with either vitellogenin-containing serum or vitellogenin alone were aborted within the first week, since most of the oocytes became whitish and eventually cytolyzed. The most important factor in this case appeared to be the female donor, which was then retired from service. Gonadotropin-treated females which initially provided a good batch of oocytes were generally poor donors for subsequent batches when these were obtained more than $48 \mathrm{hr}$ later. Our most consistent success, therefore, was achieved with well-fed, unstimulated females which initially provided a good batch of oocytes. Subsequent batches were also good if laparotomies were carefully done. The results reported below represent those cases in which $>90$ p. 100 of the oocytes survived until the end of the culture period.

Ooxyte growth as a function of vitellogenin concentration both without and with a serum supplement. - We have previously used a vitellogenin concentration of $5 \mathrm{mg} / \mathrm{ml}$ during oocyte culture. This concentration of vitellogenin essentially saturates specific sequestration by oocytes (Wallace and Jared, 1976) and therefore was expected a priori to promote optimal growth. A direct test of this assumption is provided in figure 2 . which shows 3 experiments in which the growth of $X$. laevis oocytes over a week's time

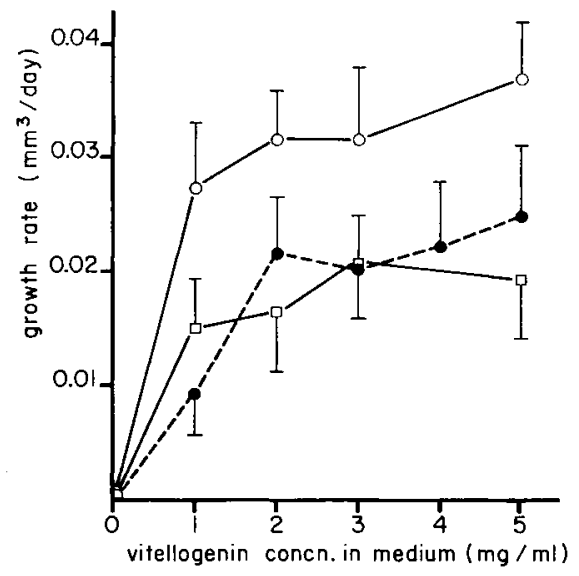

FIG. 2. - Growth rate of $X$. laevis oocytes in various concentrations of vitellogenin. Oocytes (ca.0.8-mm diameter) from 2 hCG-stimulated $(o, \square)$ and an unstimulated $(\bullet)$ female were cultured for 7 days, and the average $( \pm S D)$ daily volume increases were calculated from the measured diameters. Each point represents 9-10 oocytes. 
was measured as a function of vitellogenin concentration. Optimum growth was achieved at a vitellogenin concentration as low as $2-3 \mathrm{mg} / \mathrm{ml}$. Above this concentration the growth rate appears to increase to some extent, but not significantly.

Vitellogenin concentration was also varied by addition of increasing amounts of vitellogenin-containing serum to the culture medium. In the 3 examples provided (fig. 3a), the vitellogenin concentration in the serum varied from $100-150 \mathrm{mg} / \mathrm{ml}$, so that at the highest vitellogenin concentration $(12 \mathrm{mg} / \mathrm{ml})$, the serum content of the medium varied from 6.7 to 8.0 p. 100 . The results (fig. $3 a$ ), appear somewhat similar to those obtained for pure vitellogenin : Essentially maximum growth of $X$. laevis oocytes was achieved at a concentration around $3 \mathrm{mg} / \mathrm{ml}$; higher concentrations appear to promote greater rates of growth, but not to a significant extent.

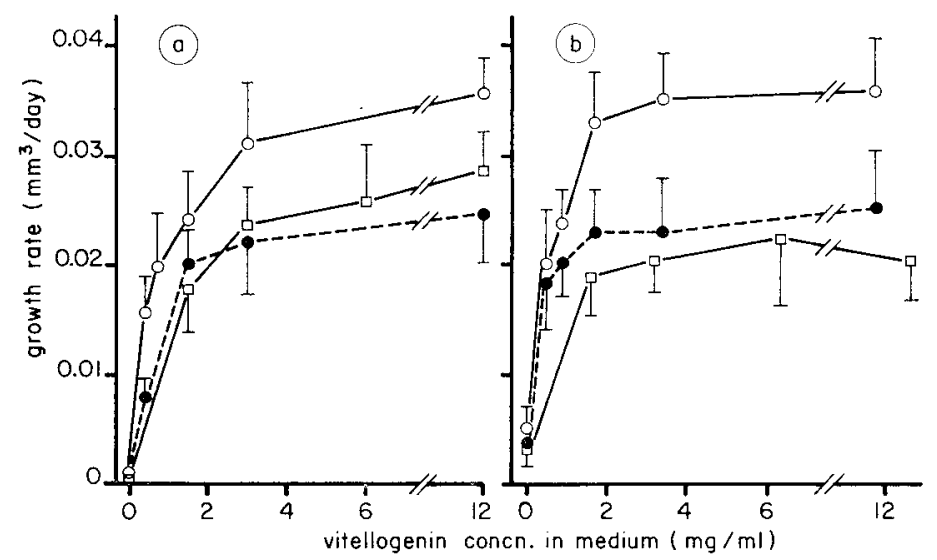

FIG. 3. - Growth rates of $X$. laevis oocyfes in various dilutions of $(a)$ vitellogenin-containing serum or (b) vitellogenin-containing serum plus male serum to yield a final serum concentration of 10 p. 100. Oocytes were isolated from unstimulated (filled symbols) or hCG-stimulated (open symbols) females and cultured for 7 days. Each point represents the average ( $\pm S D$ ) daily volume increase calculated from the diameters of 9-10 oocytes.

In a second series of experiments, the vitellogenin-containing serum was supplemented with male $X$. laevis serum to give a final serum concentration of 10 p. 100 , regardless of the vitellogenin concentration. In this case, optimum oocyte growth was decidedly achieved at a vitellogenin concentration of $2 \mathrm{mg} / \mathrm{ml}$ (fig. $3 b$ ), with higher concentrations providing no improvement. A slight amount of growth (ca. $0.004 \mathrm{~mm}^{3}$ / day) was also noted in the complete absence of vitellogenin ; this was probably due to the non-specific sequestration of serum proteins (Wallace et al., 1970).

Overall, these results indicate that for optimum oocyte growth it is desirable to maintain the serum concentration at a level of 10 p. 100 and the vitellogenin concentration at a level of at least $2 \mathrm{mg} / \mathrm{ml}$. We explored the serum supplement further by ascertaining the importance of the serum source. Accordingly, vitellogenin-containing serum was added to the medium to give a final vitellogenin concentration of $2.5 \mathrm{mg} / \mathrm{ml}$ (vitellogenin-containing serum concentration $=1.7-2.5 \mathrm{p} .100$ ), and serum from several sources was added to the medium to give a total serum concentration of 10 p. 100 . Growth rates in the presence of the various sera were compared with those achieved 
in the presence of vitellogenin alone. The results (table 1) indicate that at equivalent vitellogenin concentrations, serum-supplemented media promoted growth rates which were 7-55 p. 100 (average $=32$ p. 100) faster than that achieved in the presence of vitellogenin alone; the source of serum, however, appeared to make no difference. These results encouraged us to use fetal calf serum as the most economical serum supplement for $X$. laevis oocyte growth.

TABLE 1

Average daily growth rates of $X$. laevis oocyles in vitellogenin-containing media without and with serum supplements

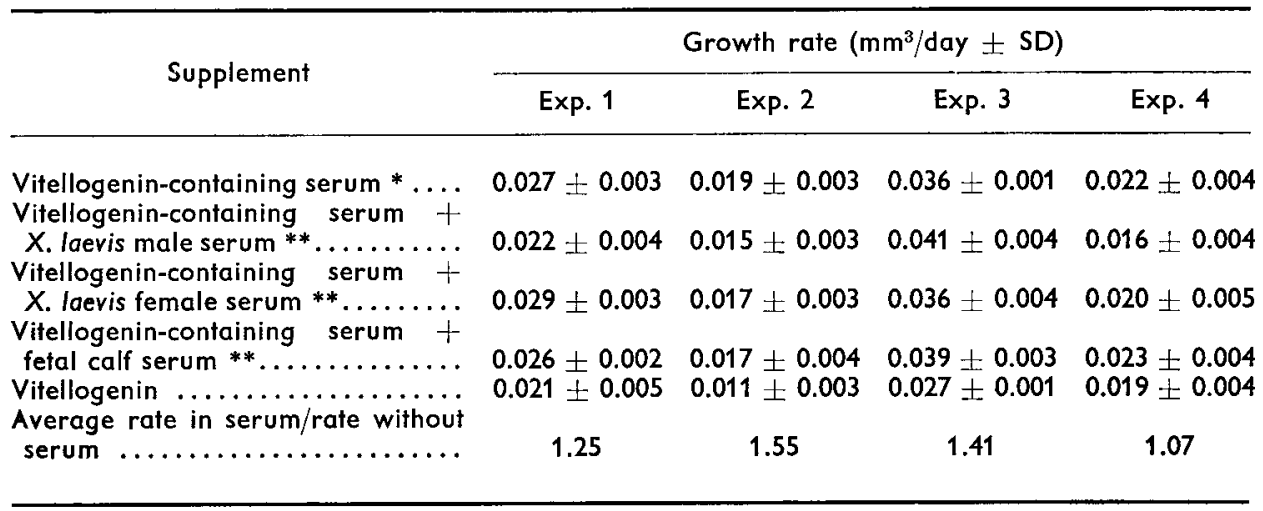

Each value represents the average daily growth rate \pm SD achieved by 9-10 oocytes over 7 days. The vitellogenin concentration in the medium was $2.5 \mathrm{mg} / \mathrm{ml}$ at all times. The female donors used for exps. 2 and 3 were previously injected with HCG, whereas those used for exps. 1 and 4 were unstimulated.

* Vifellogenin-containing serum from estrogen-treated $X$. laevis females was added to the medium to give a vitellogenin concentration of $2.5 \mathrm{mg} / \mathrm{ml}$. The final serum concentration of the medium ranged from 1.7 to 2.5 p. 100 .

** Additional serum added to vitellogenin-containing serum to give a final serum concentration of 10 p. 100 . A different source of $X$. laevis male or female serum was used for each experiment, but the same batch of fetal calf serum was used throughout.

Oocyte growth as a function of initial oocyfe size : X. laevis vs $R$. pipiens. - Since vertebrate vifellogenins appear to be incorporated specifically by anuran oocytes regardless of source (Wallace ef al., 1980), we have compared growth rates for $X$. laevis and $R$. pipiens oocytes culfured over 11-14 days in vitellogenin-containing serum obtained from $X$. laevis. In this case, the concentration of serum from estrogen-treated females was held at 10 p. 100 , the vitellogenin concentration ranged from 10 to $15 \mathrm{mg} /$ $\mathrm{ml}$ (i. e., a saturating level), and the initial oocyte diameters were $0.50-1.25 \mathrm{~mm}$ for $X$. laevis (fig. 4) and 0.7-1.2 $\mathrm{mm}$ for $R$. pipiens (fig. 5).

Maximum growth rates were achieved by $X$. laevis oocytes which were initially between 0.8 and $1.1 \mathrm{~mm}$ diameter, with larger and smaller oocytes growing at slower rates in both cases measured (fig. $4 a$ and $b$ ). Essentially no growth was achieved over 11-12 days by oocytes with a diameter of $0.5 \mathrm{~mm}$. Those oocytes which grew larger than $1.1 \mathrm{~mm}$ routinely underwent maturation when treated with progesterone, as has been previously described (Wallace and Misulovin, 1978). 


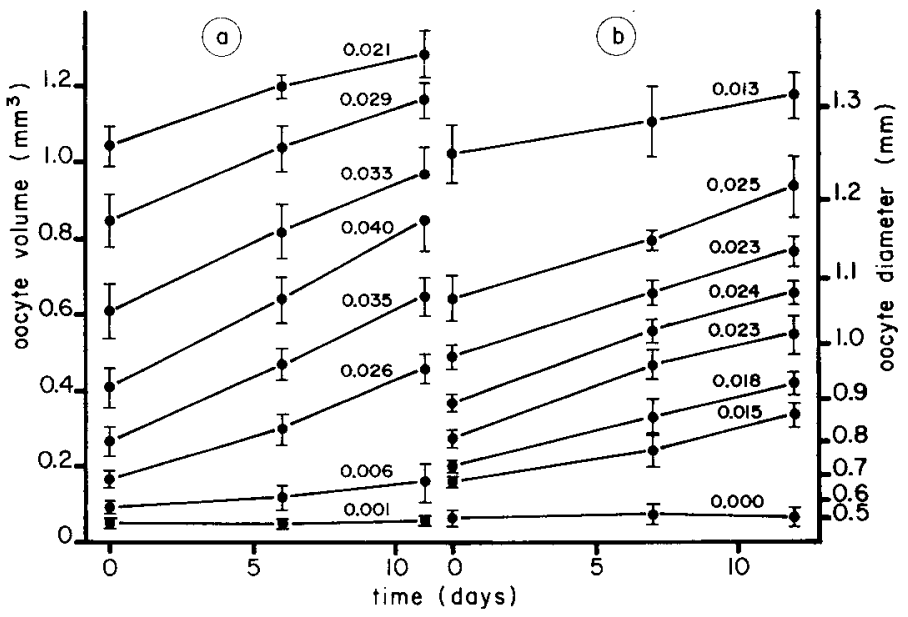

FIG. 4. - Growth of various-sized X. laevis oocytes in medium supplemented with vitellogenin-containing serum. Data for oocytes derived from 2 hCG-stimulated females are provided ( $a$ and $b$ ). Each point represents the average volume $( \pm S D)$ for 9-10 oocytes. The numbers indicate the average daily growth rates during the time of culture for each group of oocytes.

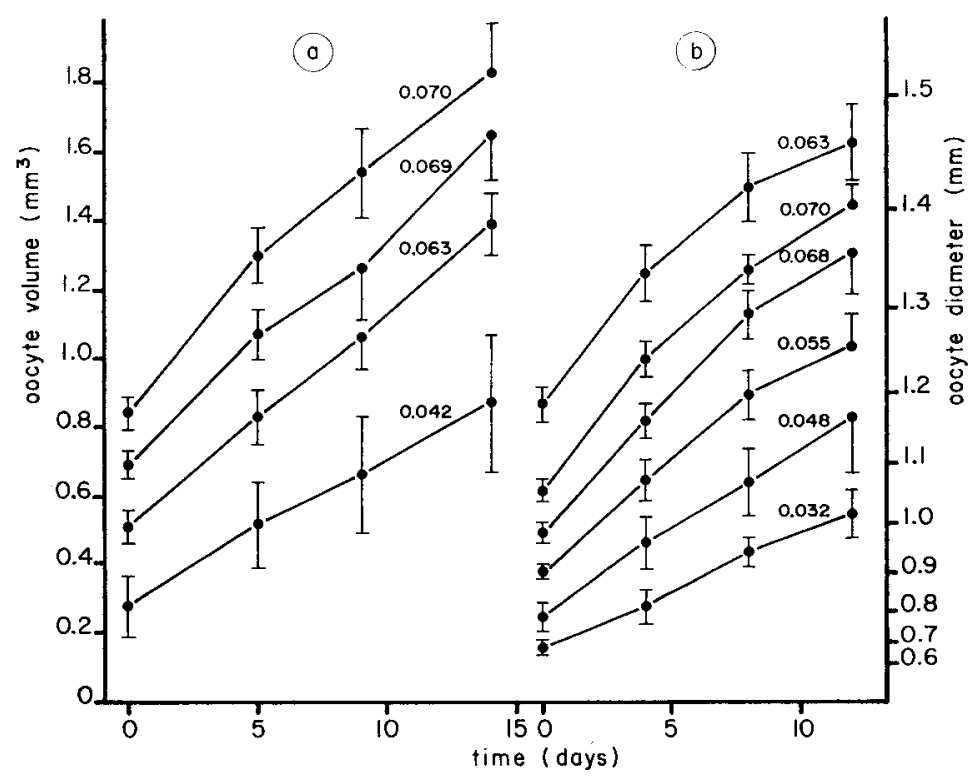

FIG. 5. - Growth of various-sized R. pipiens oocytes in medium supplemented with vitellogenin-containing serum from $X$. laevis. Data for oocytes derived from 2 pituitary-stimulated females are provided $(a$ and $b)$. Each point represents the average volume $( \pm$ SD) for 9-10 oocytes. The numbers indicate the average daily growth rate during the time of culture for each group of oocytes. 
In the case of $R$. pipiens, the size range of oocytes initially placed in culture was not as broad, so that reduced rates of growth by the largest and smallest oocytes examined were either absent or not as great as those observed for $X$. laevis (fig. $5 a$ and $b$ ). The most remarkable aspect of dala for $R$. pipiens, however, is that oocytes grew at rates which were approximately twice those achieved by $X$. laevis oocytes, even though $X$. laevis vitellogenin was used in the culture medium as the yolk precursor.

\section{Discussion.}

Eppig (1977) has recently demonstrated that oocytes from 8-day old mice can be grown in vitro in a serum-supplemented medium when enclosed in granulosa cells and that those oocytes which attain a diameter of $70 \mu \mathrm{m}$ in culture are competent to undergo spontaneous maturation when released from the granulosa cells. Although some growth has also been observed for naked mouse oocytes cocultured with granulosa cells (Baran and Bachvarova, 1977), the maintenance of junctional associations between granulosa cells and oocytes appears to be necessary for optimum oocyte growth in vitro (Eppig, 1979). Mammalian oocytes do not grow to the extent of most nonmammalian oocytes in situ, apparently because they are not specialized to sequester vitellogenin for yolk production (Wallace, 1978). Thus, at present it appears that mouse oocytes can achieve a normal albeit limited growth in vitro, that the intimate association of granulosa cells is required for normal growth, and that the presence of serum but not vitellogenin is essential.

In contrast, the much more pronounced growth of nonmammalian vertebrate oocytes is predominantly a function of yolk formation, which, in turn, depends upon the sequestration of vitellogenin from the maternal bloodstream by the oocyte (Wallace, 1978). Our initial attempts to grow $X$. laevis oocytes in vitro, therefore, involved the addition of vitellogenin to an appropriate nutrient medium. At the time, the inclusion of serum did not seem to be particularly beneficial (Wallace et al., 1978) and the presence of granulosa or follicle cells did not appear to be necessary (Wallace and Misulovin, 1978).

We have here found that when the serum concentration of the medium is held at a constant level (10 p. 100), maximum growth is achieved by $X$. laevis oocytes at a vitellogenin concentration as low as $2.0 \mathrm{mg} / \mathrm{ml}$ (fig. $3 b$ ). We have further found that when vitellogenin is held at a constant concentration of $2.5 \mathrm{mg} / \mathrm{ml}$, a 10 p. 100 serum supplement (regardless of source) promotes a growth rate which averages 32 p. 100 faster than that achieved in the absence of serum (table 1). The beneficial effect of serum was overlooked in our initial study because we measured vitellogenin uptake rather than growth per se as a criterion for an appropriate medium (Wallace et al., 1978). Thus, vitellogenin uptake will decrease with time in an inadequate medium, but it will also decrease as oocytes grow and approach their maximum size (Wallace et al., 1970 ; Keem ef al., 1979). In retrospect, therefore, the relatively poor vitellogenin uptake displayed by oocytes cultured for 2 weeks in the presence of serum may have been due to their relatively better growth.

The serum component(s) responsible for the better growth rate is unknown; presumably it is not insulin, since we always included an insulin supplement at a 
concentration $(1 \mu \mathrm{g} / \mathrm{ml})$ which is maximally effective (Wallace ef al., 1978). An alternate possibility, consistent with the observations thus far, is that vitellogenin, after it has been chromatographed in alkaline buffers on TEAE-cellulose, concentrated by ultrafiltration, and dialyzed prior to freezing, is partially denatured and hence somewhat less acceptable to the oocyte. Vitellogenin-containing serum is simply frozen right away, so vitellogenin itself is not manipulated in any way.

The growth rate as a function of initial oocyte size was measured in serumsupplemented medium over a broad size range of oocytes obtained from $2 X$. laevis females (fig. $4 a$ and $b$ ). These rates were negligible for oocytes with a diameter of $0.5 \mathrm{~mm}$; they increased to a maximum for oocytes with a diameter of 0.8-1.1 mm, and tapered off again for somewhat larger oocytes. In general, this approximates what we have found for the relative growth rates of various-sized oocytes in vivo (Keem ef al., 1979). The major difference between oocyte growth in vitro and in vivo is that cultured oocytes grow at rates which are considerably faster than those of oocytes in situ, whether from normal or hCG-treated females (Keem et al., 1979).

One of the remarkable findings presented here is that $R$. pipiens oocytes grow in vitro at rates which are approximately double those achieved by $X$. laevis oocytes (fig. 5). The two anurans are distantly related, yet $X$. laevis vitellogenin appears to be entirely satisfactory for promoting the rapid growth of $R$. pipiens oocytes. These results are consistent with our recent finding that vitellogenin sequestration by oocytes is not species-specific (Wallace et al., 1980). It appears, therefore, that the procedures we have described here for oocyte culture would generally apply for at least any amphibian and that the source of vitellogenin-containing serum would be dictated simply by economics and availability.

Reçu en août 1979

Accepté en novembre 1979.

Acknowledgment. - Research sponsored jointly by Environmental Protection Agency Agreement No. 79-D-XO533, the Office of Health and Environmental Research, U. S. Department of Energy, under contract W-7405-eng-26 with the Union Carbide Corporation, and Grant T32 GM O7431 from the National Institute of General Medical Sciences.

Résumé. Des ovocytes de dimension convenable de Xenopus laevis peuvent être cultivés in vitro, pour une durée allant jusqu'à deux semaines, dans du sérum contenant de la vitellogenine (fig. 3 et 4 ). La source de sérum semble êłre indifférente (tabl. 1). Les vitesses de croissance des ovocytes sont un peu meilleures que celles atteintes en présence de vitellogénine seule (tabl. 1). Dans des conditions identiques, les ovocytes de Rana pipiens s'accroissent environ deux fois plus vite que les ovocytes de $X$. laevis (fig. 5). Les conditions de culture décrites semblent être applicables d'une façon générale aux ovocytes d'amphibiens.

\section{References}

ANSTALL H. B., HUNTSMAN R. G., 1960. Influence of temperature upon blood coagulation in a cold- and a warm-blooded animal. Nature, 186, 726.

BARAN M. M., BACHVAROVA R., 1977. In vitro culture of growing mouse oocytes. J. exp. Zool., 202, 288-289. 
EPPIG J. J., 1977. Mouse oocyte development in vitro with various culfure systems. Develop. Biol., $60,371-388$.

EPPIG J. J., 1979. A comparison between oocyte growth in coculture with granulosa cells and oocyles with granulosa cell-oocyte junctional contact maintained in vitro. J. exp. Zool., 209, 345-353.

KEEM K., SMITH L. D., WALLACE R. A., WOLF D., 1979. Growth rate of oocytes in laboratorymaintained Xenopus laevis. Gamete Res., 2, 125-135.

WALLACE R. A., 1970. Studies on amphibian yolk. IX. Xenopus vitellogenin. Biochim. biophys. Acta, 215, 176-183.

WALLACE R. A., 1978. Oocyte growth in nonmammalian vertebrates, 469-502, in JONES R. E., The vertebrate ovary, Plenum, New York.

WALLACE R. A., JARED D.W., 1976. Protein incorporation by isolated amphibian oocytes. V. Specificity for vitellogenin incorporation. J. Cell Biol., 69, 345-351.

WALLACE R. A., MISULOVIN Z., 1978. Long term growth and differentiation of Xenopus oocytes in a defined medium. Proc. nat. Acad. Sci. USA, 75, 5534-5538.

WALLACE R. A., JARED D.W., NELSON B. L., 1970. Protein incorporation by isolated amphibian oocytes. I. Preliminary studies. J. exp. Zool., 175, 259-269.

WALLACE R. A., JARED D. W., DUMONT J. N., SEGA M. W., 1973. Protein incorporation by isolated amphibian oocytes. III. Optimum incubation conditions. J. exp. Zool., 184, 321-334.

WALLACE R. A., MISULOVIN Z., JARED D. W., WILEY H. S., 1978. Development of a culture medium for growing Xenopus laevis oocytes. Gamete Res., 1, 269-280.

WALLACE R. A., DEUFEL R. A., MISULOVIN Z., 1980. Protein incorporation by isolated amphibian oocytes. VI. Comparison of autologous and xenogeneic vitellogenins. Comp. Biochem. Physiol., 65 B, 151-155.

WILEY H. S., OPRESKO L., WALLACE R. A., 1979. New methods for the purification of vertebrate vitellogenin. Anal. Biochem., 97, 145-152. 